\title{
Epidemiology of Hepatitis Delta Virus infection in HIV-infected individuals in Taiwan
}

\author{
Hsi-Hsun Lin*, Susan Shin-Jung Lee, Ming-Lung Yu, Bo-Sean Hu, Shiou-Haur Liang, Wen-Chien Ko, Jaw-Ching Wu, \\ Fan-Ceng Zheng, Chung-Hsu Lai, Jin-Long Lin
}

From 17th International Symposium on HIV and Emerging Infectious Diseases (ISHEID)

Marseille, France. 23-25 May 2012

\section{Introduction}

HIV-infected individuals are at higher risk for acquiring HDV. We sought to study the prevalence, genotypes, and associated risk factors causing HDV infection in HIV-infected individuals from an area with high prevalence of hepatitis B virus infection.

\section{Materials and methods}

A multicenter study of 341 (22.1\%) HBsAg+ from 1543 HIV-infected patients was conducted from 2005 through 2011. Blood samples were collected and analyzed for the presence of antibody to HDV and to determine the genotype of HDV.

\section{Results}

The overall prevalence of HDV infection among HBsAg+ carriers was $54.8 \%$ (187/341). However, the prevalence among different risk group was distinct. The prevalence of HDV was $73.6 \%, 13.5 \%$, and $9.2 \%$ among HIV-infected IDUs, heterosexual, and MSM, respectively. The main circulating HDV subtypes in our study were genotype IV (60.5\%), genotype II (27.6\%), and genotype I (11.8\%). Multivariate logistic regression analysis revealed that the major risk factor associated with HDV infection was injection drug use, following by HCV infection, HBsAg titer $>=250$ $\mathrm{IU} / \mathrm{mL}$, and duration of injection drug use. A significant increase of cumulative seroprevalence of HDV with duration of IDU from 1 to 15 years was observed (OR: 1.20, 95\% CI: 1.09-1.32, $\mathrm{P}<0.01)$.

\section{Conclusions}

Our study demonstrated high prevalence of HDV infection among HIV-infected IDUs. Effective strategies are

* Correspondence: ed100233@yahoo.com.tw

E-Da Hospital, I-Shou University, Kaohsiung, Taiwan, Province of China needed to prevent injection drug use and to educate ongoing IDUs about the avoidance of practices that lead to infection with HIV, HCV, and HDV.

Published: 25 May 2012

doi:10.1186/1742-4690-9-S1-P49

Cite this article as: Lin et al:: Epidemiology of Hepatitis Delta Virus infection in HIV-infected individuals in Taiwan. Retrovirology 2012 9(Suppl 1):P49.
Submit your next manuscript to BioMed Central and take full advantage of:

- Convenient online submission

- Thorough peer review

- No space constraints or color figure charges

- Immediate publication on acceptance

- Inclusion in PubMed, CAS, Scopus and Google Scholar

- Research which is freely available for redistribution
C Biomed Central

\section{() BioMed Central}

